\title{
鼻腔髄外形質細胞腫の一例と実験的分析
}

\author{
藤枝 重治・斎藤等・前川 謙一・杉本 千鶴
}

\section{A Case of Extramedullary Plasmacytoma in the Nasal Cavity and Its Experimental Analyses}

\author{
Shigeharu Fujieda, Hitoshi Saito, Ken-ichi Maekawa and Chizuru Sugimoto \\ (Fukui Medical School)
}

\begin{abstract}
We report a case of extramedullary plasmacytoma in the nasal cavity. Production and secretion of immunoglobulins were not detected in the tumor by immunohistochemistry and electrophoresis. However, it was surprising that this tumor had higher cytotoxic activity against K-562 tumor cells than peripheral blood lymphocytes. The surface marker of these plasma cells was determined to be $\mathrm{CD}^{-}, \mathrm{CD}^{-}, \mathrm{CD}^{-}, \mathrm{CD}^{-} 6^{-}$and $\mathrm{CD} 54^{+}$ by FACSter. This result indicated that these plasma cells were more undifferentiated than normal plasma cells in mucosa-associated lymphoid tissues (MALT). The existence of undifferentiated plasma cells in the nasal cavity suggested that plasma cells in MALT have an autocrine and auto-generated system.
\end{abstract}

Key words: extramedullary plasmacytoma, nasal cavity, natural killer activity, mucosa-associated lymphoid tissues

はじめに

形質細胞腫は，骨髄に多発性に発生する多発 性骨䯣腫がよく知られているが，形質細胞腫の 10\%以下に孤立性の形質細胞腫が存在する。そ れらは骾外形質細胞腫 (extramedullary plasmacytoma) と孤立性骨形質細胞腫 (solitary plasmacytoma of bone) に分類され, 䯣外形質細胞腫 は頭頸部領域に多いとされている1122。 しかし ながら頭頸部腫瘍においては, 䯣外形質細胞腫 は稀な疾患である，今回，鼻腔を原発とする髄 外形質細胞腫を経験したので, 免疫グロブリン の産生や細胞性免疫学的検討を加光報告すると ともに, 鼻腔局所免疫における形質細胞の進化 について言及する。
症例

50歳, 女性, 契茶店経営.

初診：1992年 2 月17日.

主訴：左鼻閉および左鼻出血.

既往歴・家族歷 : 特になし。

現病歴：1992年 1 月中旬頃より左鼻閉が出現, 頻回の鼻出血を伴らようになった．そのため近 医を受診, 左鼻腔内の易出血性ポリープを指摘 され，手術目的に当科紹介となった。

〈鼻内所見〉

鼻腔内は易出血性の腫瘍が存在し, 下鼻甲介 との境界が不明膫であった．中鼻道には易出血 性の腫瘍とは異なった通常のポリープが存在し た（図 1 ). 


\section{〈X線像〉}

左上顎洞は軽度の粘膜肥厚を認女，左篩骨洞 にはびをん性の陰影を認めた，右上顎洞篩骨洞 は正常であった（図 2 ）。

\section{〈手術所見〉}

術前の診断では, 慢性副鼻腔炎に伴う易出血 性のポリープであるらと考光，1992年4月 2 日 局所麻酔下に左上䋶洞篩骨洞根本術を施行した。



図 1 初診時鼻腔内所見

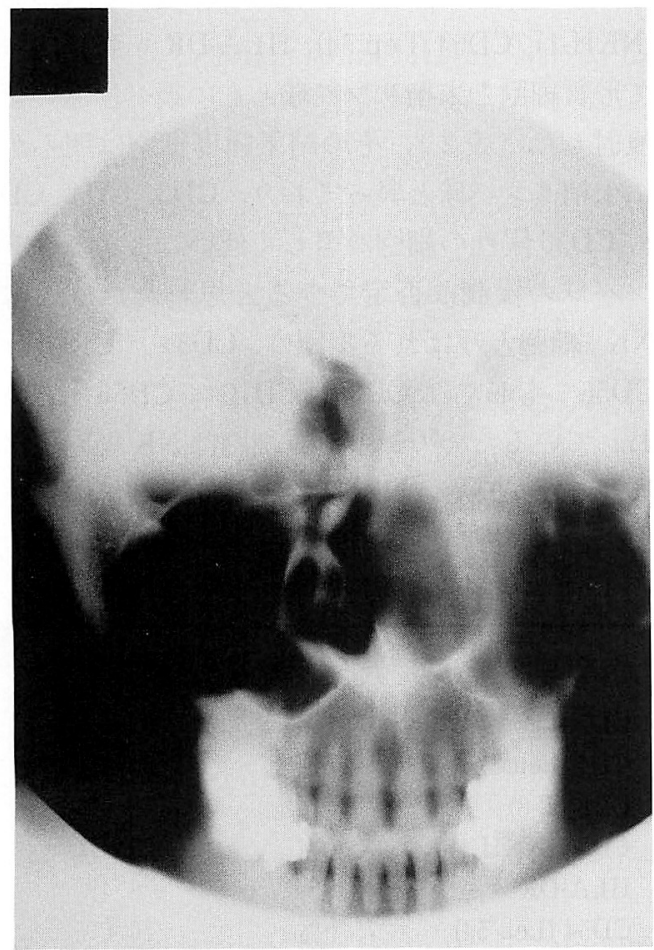

図 2 単純X線像
左上顎洞は粘膜肥厚のみで慢性副鼻腔炎の像で あった．一方左鼻腔の易出血部を術中迅速病理 に提出したところ形質細胞腫の診断を受けたた め術式を和辻-Denkel 法に変更し, 下鼻甲介, 鼻腔側壁を一塊にして切除し篩骨洞を大きく開 放した．篩骨洞内は慢性副鼻腔炎でめり，腫瘍 などは存在しなかった，摘出標本を四 3 に示す。 下方に下鼻甲介後端がありそれに引き続いて上 方に腫瘍が存在する.

〈病理組織学的検査〉

胞体が大きく，細胞質が豊富で核の大小不同 があり，核が一側に偏位していた。また 2 核細 胞や車輪状の核，それに核周明庭とよばれる明 るい部分が認められる, 典型的な形質細胞腫で あった（図 4)。

〈治療経過〉

術後，形質細胞腫の診断が確定したため鼻腔

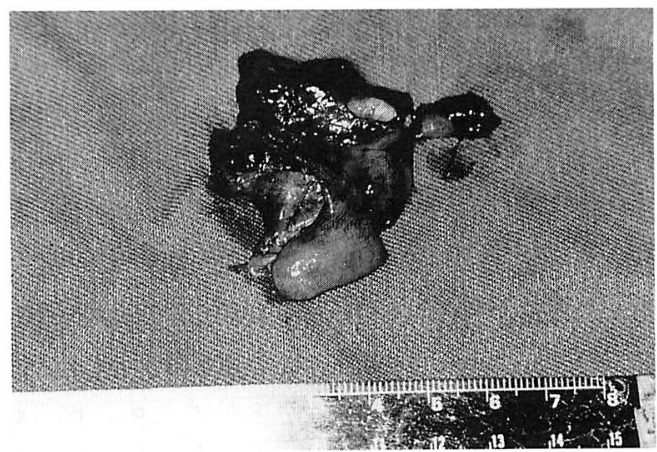

図 3 手術時摘出標本

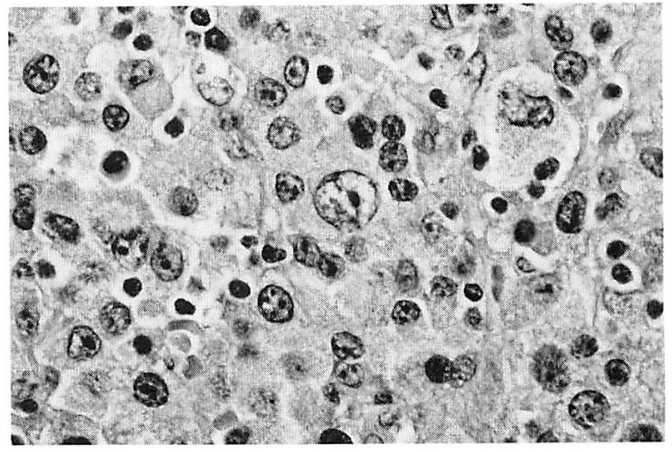

図 4 摘出腫瘍の組織像 $(\mathrm{H}-\mathrm{E}$ 染色 $\times 400)$ 
の原発巣に $52 \mathrm{~Gy}$ の放射線治療を行なった. $\mathrm{Ga}$ シンチでは左側頭部に集積を認めたため生検を 行なった。しかし核の変性と破壊を認めたのみ で明らかな形質細胞腫は認めなかったが $46 \mathrm{~Gy}$ の放射線治療を併用した。

現在外来にて経過観察中であるが局所再発並 びに遠隔転移は認めていない。

〈生化学, 血清免疫学的所見〉

血清中の生化学, 免疫学的検査では電気泳動 にて M-peak 出現はなく, 血清中免疫グロブリ ンの異常や骨髄所見の異常も認めなかった，尿 中の Bence-Jones (B-J) 蛋白も出現しておらず, 腎機能なども全く正常であった（表 1 ）.

〈腫瘍細胞産生免疫グロブリン〉

腫瘍組織を機械的かつ酵素処理にて単細胞に し344) 腫瘍細胞の塗沫標本を作り, 腫瘍の産生 する免疫グロブリンの同定を試みた．塗洙標本 を固定後 PAP 法にて抗ヒト $-\alpha, \gamma, \mu, \kappa, \lambda$ 鎖抗 体を用いて行なったが，何も染色されなかった。 そこで腫瘍細胞を10\%胎児牛血清加 RPMI-1640 にて培養後24時間，さらには10日目の腫瘍細胞 と培養上清を採取し, 腫瘍細胞は前述の PAP 法にて染色を, 培養上清は免疫電気泳動にかけ た。しかしながら腫瘍細胞は染色されず，免疫 電気泳動に拈いても図 5 a に示すよらに沈降線 は存在しなかった。そこでこの培養上清を10倍 から50倍濃縮して電気泳動をかけたが，図 5 b

\section{表 1 検査成績}

TP $8.1 \mathrm{~g} / \mathrm{dl} \quad \gamma$-globulin $16.5 \% \quad$ A/G 1.18

CH50 36.9

IgG $1535 \mathrm{mg} / \mathrm{dl} \quad$ IgA $115 \mathrm{mg} / \mathrm{dl} \quad$ IgM 122 $\mathrm{mg} / \mathrm{dl}$

直接 coombs test (-) 間接 coombs test $(-)$

尿中 B-J 蛋白 $(-)$ 尿中 albumin 6.2

腎機能 : 正常

ALP $144 \mathrm{mg} / \mathrm{dl}$ Ca $4.5 \mathrm{mEq} / 1$

末梢血 : anemia (-) rouleaux formation $(-)$

骨䯣生検 : atypical plasma cell (-) plasma cell: $1.2 \%$

血清蛋白免疫電気泳動 M-peak (-)
に示寸ように $\alpha_{2}$ ぐらいのところに沈降線が認 められたが， $\gamma$-グロブリンの沈降線は認められ なかった， $\alpha_{2}$ の沈降線は技々らく胎児牛血清 のものであると思われる. 以上より免疫グロブ リン非産生性, 非分泌型の腫瘍であると判定し た.

〈腫瘍細胞の殺細胞活性と細胞表面マーカー の分析〉

そこで腫瘍細胞の特性を検討する目的で，単 離細胞にした形質細胞の K-562 に対する細胞 障害活性を測定した．同時に末梢リンパ球の活 性も測定した。方法は標識した K-562 と, 形 質細胞もしくは末梢リンパ球を各々の effector to target ratio $(\mathrm{E} / \mathrm{T})$ にて通常の 4 時間 ${ }^{51} \mathrm{Cr}$ 放 出試験で行なった5). 結果を図 6 に示すが，驚 くべきことに K-562 に対する細胞障害活性は, 形質細胞自身の方が末梢リンパ球よりも高かっ た。つまり形質細胞自身が高い NK 活性を持 っていたといらことであった.そこで FACSter にて CD3 (Leu 4), CD4 (Leu 3), CD8 (T8), CD56 (NKH-1), CD54 (Leu 54), HLA-DR を直接法に て形質細胞と末梢りンパ球ともに調べ，違いを 検討した（表 2 ）。その結果腫瘍細胞は明らか に末梢リンパ球と異っており, CD3, CD 4, CD 8, CD56 陽性の細胞が著しく低いことより，リ ンパ球の浸潤は否定できると思われた，通常 $\mathrm{NK}$ 細胞と呼ばれる集団は $\mathrm{CD}^{-}-, \mathrm{CD}^{-} 6^{-}$, $\mathrm{CD}_{6} 6^{+}$もしくは CD3-, $\mathrm{CD} 16^{+}, \mathrm{CD}^{2} 6^{+}$とい われているため ${ }^{6)}$, この形質細胞は NK 細胞とは 異なりながらも，NK 活性を持つ細胞集団とい

表 2 細胞表面マーカー

\begin{tabular}{lcc}
\hline \hline & 腫瘍細胞 & 末梢リンパ球 \\
\hline CD3 (Leu 4) & $3.0 \%^{*}$ & $65.6 \%$ \\
CD4 (Leu 3) & $0.6 \%$ & $34.2 \%$ \\
CD8 (T-8) & $2.1 \%$ & $22.8 \%$ \\
CD56 (NKH-1) & $2.0 \%$ & $22.2 \%$ \\
HLA-DR & $8.8 \%$ & $8.4 \%$ \\
CD54 (Leu 54) & $75.0 \%$ & $16.6 \%$
\end{tabular}

*全細胞中の陽性率 

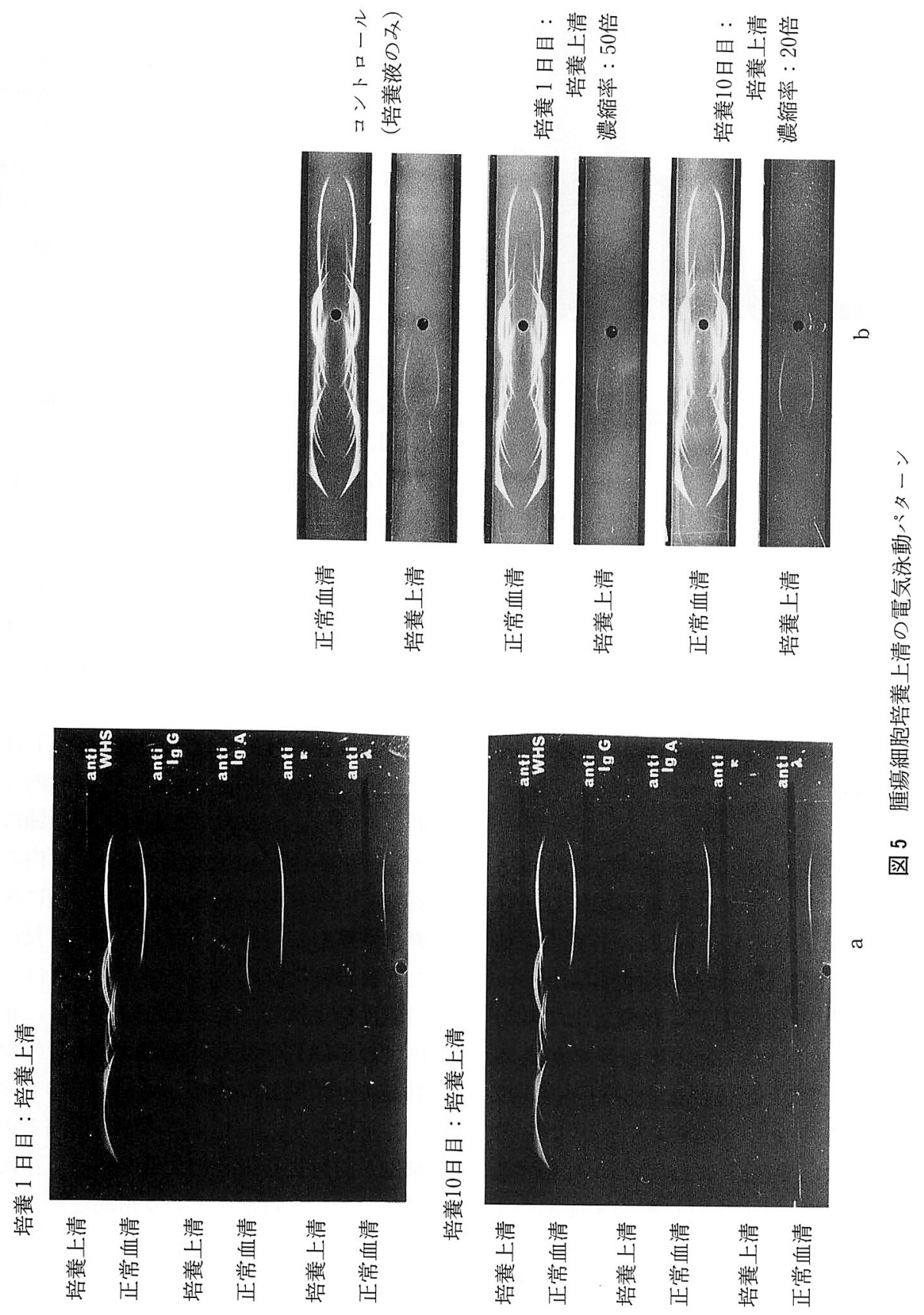


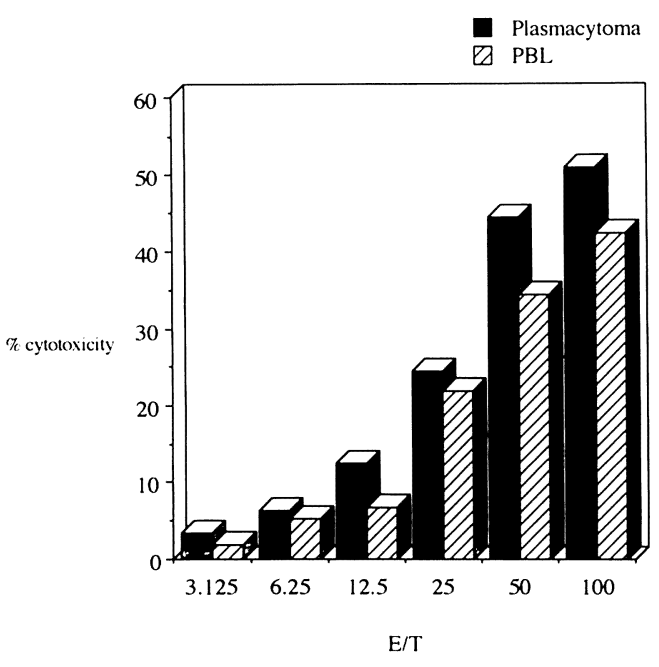

図 6 K-562 に対する細胞障害試験 $\left(4 \mathrm{hr}-{ }^{51} \mathrm{Cr}\right.$ 放出試験)

える.腫瘍細胞の陽性コントロールとして CD 54 (ICAM-1) を調べたところ大多数の細胞が染 色された。次に NK 活性を持っていたため, インターリュウキン -2 存在下に腫瘍細胞の培 養を行なった。しかし末梢血のように増殖など は認められず, インターリュウキンー6 存在下 やマイトマイシン処理線維芽細胞を feeder cell として細胞株樹立も試みたが7成功しなかった。

\section{考察}

髄外性形質細胞腫の症例は本邦でもかなり報 告されている ${ }^{8)}$ 12). 骨道外性形質細胞腫の予後 は, 中間生存率が 63 力月から124力月程度之他 の孤立性骨形質細胞腫や多発性骨髄腫に比べ一 般に良いとされている213)14). 治療として放射 線治療を第一選択とする論文も幾つかある が(13) 17), 手術療法と術後照射の併用の方が成 績が良いと報告されている論文もある18)19)。放 射線に対寸る反応も良好で注ぼ90\%が反応する ようである2)13)14). 以上より口腔や本症例のよ らな鼻副鼻腔原発の場合には，やはり手術が第 一選択であり，その後，術後照射を行ならのが 良いとわれわれは考えている。

形質細胞腫の特徵としてM蛋白の産生が認め られているが，孤立性骨形質細胞腫では血清中
のM蛋白出現がない力が予後が良く，一種の予 後因子になりらると報告されている20). 本邦で も様々な型の免疫グロブリンの産生が報告され ているが8) 12), 本症例では産生を認めなかっ た. Meis らによると13例中11例免疫グロブリ ンの産生を認めて拈り18)，かなりの髄外形質細 胞腫は何らかの免疫グロブリンを産生している と思われる。しかし血清中のM蛋白の出現はあ まり認めず， ほとんど非分泌型であろらと述べ ている.このことが，髄外形質細胞腫の予後が 比較的良いことと関連するのかもしれない.

さらに彼らは，孤立性骨形質細胞腫に比べ髄 外形質細胞腫では IgA 型が多いため, 腫瘍が 上気道の mucosa-associated lymphoid tissue (MALT) の正常形質細胞から発生したもので あろらと推測している。同様のことは本邦でも 言われているが21)，われわれは本症例の腫瘍細 胞が NK 活性を持っていたことを考えると， 正常形質細胞よりもっと未分化なものより発生 したと考えざるを得ない，NK 活性を持つ細胞 は進化論上，キラー T 細胞の分化段階よりも前 に位置すると言われていることより6)，以下の 二つの仮説が考えられる. 一つは，T-B 細胞分 化以前のものが骨髄より出て, 鼻腔内で異様に 進化，増殖してこのような形質細胞腫になった といら可能性, も5一つは MALT 内の正常形 質細胞が脱分化し一旦未分化な細胞に戻って, 異常増殖した可能性である. 骨髄所見にて異常 な形質細胞は認められなかったことは，両者の 可能性を支持している。このことは，正常鼻腔 内での MALT の形質細胞は，未分化な細胞が 骨髄より循環してきて，MALT 内で分化して いく可能性か，もしくは MALT 内で正常形質 細胞が脱分化し未分化な細胞に戻った後，再度 増殖, 分化を行ならといら可能性が考えられる. すなわち MALT 内の形質細胞は，常に骨髅よ り分化した形質細胞が供給されるのではなく， MALT 内で脱分化, 再増殖, 分化を含めて自 己増殖できうる可能性が高いと思われる。 髄外形質細胞腫の多発性骨髄腫への移行は, 
頭頸部の場合 $8 \%$ から $35 \%$ で移行したとの報告 から13) 19) 決して低くない。また局所再発はも ちろんのこと所属りンパ節での転移も認められ， それも 5 年から 10 年, 時には 10 年以上過ぎてか ら起こることも多いようであり2)，長時間の経 過観察が必要であろうと思われる。

\section{まとめ}

鼻腔原発の䯣外形質細胞腫の一症例を経験し た．免疫グロブリン非産生型, 非分泌型であっ たが，腫瘍自身が NK 活性を持っていた。こ のことは MALT の形質細胞の分化を知るうえ で重要であろらと思われた。

本論文の一部は第261回日耳鼻北陸地方部会連合会 にて発表した.

\section{文 献}

1) Castro EB, Lewis JS and Strong EW : Plasmacytoma of paranasal sinuses and nasal cavity. Arch Otolaryngol $93:$ 326 329, 1973.

2) Knowling MA, Harwood AR and Bergsagel DE : Comparison of extramedullary plasmacytomas with solitary and multiple plasma cell tumors of bone. J Clin Oncol 1 : 255 262, 1983.

3) Fukui $Y$, Iseki $R$ and Ohashi $M$ : Lymphokine activated killer activity against autologous malignant tumor of skin. J Invest Dermatol $91:$ 319 322, 1988.

4) Tanigawa N, Kern DH, Hisaka $Y$, et al : Rapid assay for evaluating the chemosensitivity of human tumors in soft agar culture. Cancer Res $42:$ :2159 2164, 1982.

5) Fujieda $S$, Saito $H$ and Hoshino $T$ : Responses of killer cells in head and neck cancer patients. Eur Arch Otorhinolaryngol 247 : 176 181, 1990.

6）八木田正人：NK 細胞一研究の進歩と最近の 動向一. 腫瘍免疫 一研究の新展開 (内田温土 編). 179 188頁, 中外医学社, 東京, 1992.

7）清水史郎, 紺田 進: 多発性骨随腫之細胞増殖 因子. Medical Immunol $23: 53 \sim 61,1992$.

8）石部司, 須藤直広, 丹家聖化, 他：IgA, IgM 産生鼻部形質細胞腫の一症例. 耳鼻臨床 74 : 2651 2660, 1981.
9）武田哲男, 清水元博, 田中康夫, 他 : $\kappa$ 型 light chain 産生上靧洞髄外形質細胞腫の一例. 耳㗋 $55:$ 515 520, 1983.

10）中村光士郎, 玉貫真比古, 丘村 熙: 鼻腔原発 の IgA 産生型鹃迶外性形質細胞腫の一例. 耳喉 $56: 209 \sim 213,1984$.

11）佐藤幸弘, 折田洋造, 山本英一, 他 : IgG- $\lambda$ 型 産生上買洞道迶外形質細胞腫の一例．耳喉 57 : $525 \sim 529,1985$.

12）白沢昭弘, 杉田尚史, 上出洋介, 他 : 右上顎洞 眼窩壁より発生したと思われる $\operatorname{IgA}$-入 型檤外形 質細胞腫の一例. 耳展 $33: 243 \sim 248,1990$.

13) Corwin J and Lindberg RD : Solitary plasmacytoma of bone VS extramedullary plasmacytoma and their relationship to multiple myeloma. Cancer 43 : 1007 1013, 1979.

14) Holland J, Trenker DA, Wasserman $T H$, et al : Plasmacytoma. Cancer 69 : 1513 1517, 1992.

15) Woodruff RK, Whittle JM and Malpas JS: Solitary plasmacytoma. Cancer $43: 2340 \sim$ 2343, 1979.

16) Tong D, Griffin TW, Laramore GE, et al : Solitary plasmacytoma of bone and soft tissues. Radiology $135: 195 \sim 198,1980$.

17) Mendenhall CM, Thar TL and Million RR : Solitary plasmacytoma of bone and soft tissue. Int J Radiat Oncol Biol Phys 6 : 1497 1501, 1980.

18) Meis JM, Butler JJ, Osborne BM, et al : Solitary plasmacytomas of bone and extramedullary plasmacytomas. Cancer 59 : 1475 1485, 1987.

19) Petrovich $Z$, Fishkin $B$, Hittle RE, et al : Extramedullary plasmacytoma of the upper respiratory passages. Int J Radiat Oncol Biol Phys 2 : 723 730, 1977.

20) Delauche-cavallier MC, Laredo JD, Wybier M, et al : Solitary plasmacytoma of the spine. Cancer $61: 1707 \sim 1714,1988$.

21）柳田則之, 稲福 繁, 西村瑞章, 他: IgA 産生 鼻咽腔形質細胞腫. 耳喉 $47: 83 \sim 91,1975$.

$\left(\begin{array}{l}\text { 別刷請求先: 藤枝重治 } \\ \overline{\mathbf{T}} 910-11 \text { 福井県吉田郡松岡町下合月 23-3 } \\ \text { 福井医科大学耳鼻咽喉科学教室 }\end{array}\right)$ 